\title{
STUDY OF HYDROPONIC SYSTEMS AND THEIR VARIATIONS
}

\section{ARUN MAURYA, VARADA MENON, VISHWAS SONWANE, SUNIT THAKUR \& GIRISH PAI}

Department of Biotechnology, MGM's college of Engineering and Technology, Navi Mumbai, India

Hydroponics is a method of agriculture using mineral nutrient solutions, in water, without the use of soil. Soil-based plants can be grown either with their roots in the mineral nutrient solution or in perlite or gravel, which is an inert medium. There are various advantages to using hydroponics over traditional crop-growing methods. The advantages include expedited plant growth, control of nutritional values, easy correction of deficiencies; growing environment can be controlled - including pests, diseases and fungi. There are a few basic types of hydroponic systems that can be used according to requirement-Ebb and Flow culture, Deep Water culture, Nutrient Film Technique (NFT) and Aeroponics. In this project we have attempted to grow Spinacia oleracea (spinach), using Kratky's noncirculating hydroponics. This method was chosen based on the ease of handling and the use of minimalistic equipment, to arrive at the result. The course of action will be to primarily establish a control system, using Hoagland's media (inorganic media). Parameters like temperature, pH and EC (electrical conductivity) will be monitored. Comparisons will then be made between plants grown in the control system to a) plants grown in a system whose nutrient solution is made with tap water and parameters have not been monitored; b) plants grown in vermiliquid (organic media). Parameters to be checked are number of days required for full growth of plant, plant height, leaf area, colour of leaves and the presence of dense roots. Protein estimation of each of the products will also be done and the results compared with traditionally grown spinach.

KEYWORDS: Kratky's Method, Spinacia Oleracea, Nutrient, Non-Circulating System, Nutrient Estimation \& Vermiliquid
\end{abstract}

Received: Aug 26, 2017; Accepted: Sep 20, 2017; Published: Oct 16, 2017; Paper Id.: IJASROCT201764

\section{INTRODUCTION}

Agriculture is incontrovertibly the largest livelihood provider in India, especially in the rural areas, in that it contributes a significant figure to the Gross Domestic Product (GDP). At present, India holds the second position in the world in agricultural production. In addition, the sector recruits about $50 \%$ of the entire manpower.

\section{GDP - Composition, by Sector of Origin}

Agriculture - $16.1 \%$, Industry $-29.5 \%$, Services $-54.4 \%$ (2015 est.)

Labour Force - by Occupation

Agriculture - 49\%, Industry - 20\%, Services - 31\% (2012 est.) ${ }^{[8]}$

"Hydroponics" is derived from the Greek word "hydro", which translates to water and "ponis", which translates to work. Since, water is the main component in any hydroponics system, it is crucial that, the good quality water supply is used. 


\section{KRATKY METHOD}

The Kratky hydroponic method is a one-of-its-kind powerful system, for growing plants because, the entire crop requires only an initial application of water and nutrients. This type of suspended pot, non-circulating system is extremely efficient with water use and reduces wastage.

The salient features of this type of non-circulating hydroponic system include:

- There should be a gap between the top cover and nutrient solution so that the upper portion of the root system is exposed to air which has high relative humidity;

- $\quad$ Roots should never be allowed to dry out;

- The lower portion of the root system should be dipped in water so as to enable the assimilation of water and nutrients;

- The roots should not be allowed to 'drown' in the water, hence the nutrient solution level can remain the same or can be lowered, but it cannot be raised.

In this system, plants grow in a small amount of inert medium held by a perforated container which is sustained by a fixed top cover over a tank.

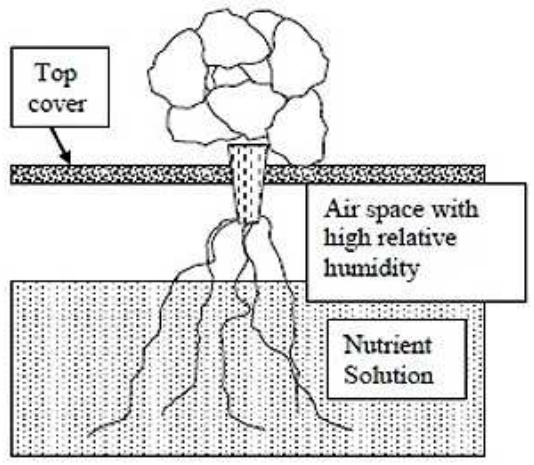

Figure 1.1: A Model Suspended Pot, Non-Circulating Hydroponic System after the Nutrient The solution has Dropped below the Seedling Container

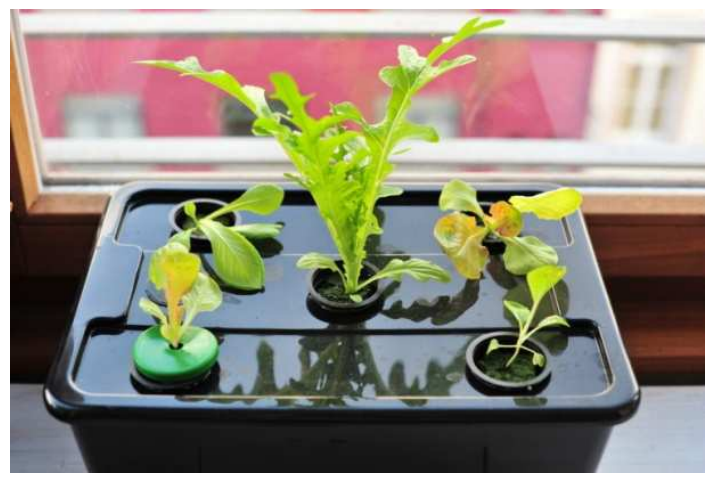

Figure 1.2: Kratky Method 


\section{MATERIALS AND METHODS (Inorganic)}

MATERIALS REQUIRED

Nutrient: Hoagland's medium

Table 1.1: Composition of Hoagland's Medium ${ }^{[1]}$

\begin{tabular}{|c|c|c|}
\hline COMPONENT & STOCK SOLUTION & $\begin{array}{c}\text { mL STOCK SOLUTION/ } \\
1 \mathrm{~L}\end{array}$ \\
\hline \multicolumn{3}{|c|}{ MACRONUTRIENTS } \\
\hline $2 \mathrm{M} \mathrm{KNO}_{3}$ & $202 \mathrm{~g} / \mathrm{L}$ & 2.5 \\
\hline $1 \mathrm{M} \mathrm{Ca}\left(\mathrm{NO}_{3}\right)_{2} \cdot 4 \mathrm{H}_{2} \mathrm{O}$ & $236 \mathrm{~g} / 0.5 \mathrm{~L}$ & 2.5 \\
\hline Iron (Iron Chelate Fe-EDTA) & $15 \mathrm{~g} / \mathrm{L}$ & 1.5 \\
\hline $2 \mathrm{M} \mathrm{MgSO}_{4} \cdot 7 \mathrm{H}_{2} \mathrm{O}$ & $493 \mathrm{~g} / \mathrm{L}$ & 1 \\
\hline $1 \mathrm{M} \mathrm{NH}_{4} \mathrm{NO}_{3}$ & $80 \mathrm{~g} / \mathrm{L}$ & 1 \\
\hline \multicolumn{3}{|c|}{ MICRONUTRIENTS } \\
\hline $\mathrm{H}_{3} \mathrm{BO}_{3}$ & $2.86 \mathrm{~g} / \mathrm{L}$ & 1 \\
\hline $\mathrm{MnCl}_{2} \cdot 4 \mathrm{H}_{2} \mathrm{O}$ & $1.81 \mathrm{~g} / \mathrm{L}$ & 1 \\
\hline $\mathrm{ZnSO}_{4} \cdot 7 \mathrm{H}_{2} \mathrm{O}$ & $0.22 \mathrm{~g} / \mathrm{L}$ & 1 \\
\hline $\mathrm{CuSO}_{4} .5 \mathrm{H}_{2} \mathrm{O}$ & $0.051 \mathrm{~g} / \mathrm{L}$ & 1 \\
\hline $\mathrm{H}_{3} \mathrm{MoO}_{4} \cdot \mathrm{H}_{2} \mathrm{O}$ or & $0.09 \mathrm{~g} / \mathrm{L}$ & 1 \\
\hline $\mathrm{Na}_{2} \mathrm{MoO}_{4} \cdot 2 \mathrm{H}_{2} \mathrm{O}$ & $0.12 \mathrm{~g} / \mathrm{L}$ & 1 \\
\hline \multicolumn{3}{|c|}{ PHOSPHATE } \\
\hline $1 \mathrm{M} \mathrm{KH}_{2} \mathrm{PO}_{4}$ (pH to 6.0$)$ & $136 \mathrm{~g} / \mathrm{L}$ & 0.5 \\
\hline
\end{tabular}

Procedure to make Hoagland's medium:

- Firstly, make the stock solutions and store these in separate bottles with suitable labels for later use.

- Next, add each component to $800 \mathrm{~mL}$ deionized water, and then fill to $1 \mathrm{~L}$.

- After the solution is mixed, it is ready for the water plant

\section{Instruments}

Thermometer, PL lights (36 watt), pH meter, EC meter, UV spectrophotometer, AC, water bath.

\section{Other Materials}

Crate, thermocol, net pots, perlite or coco peats, aluminium foil, cardboard, pellets, mortar and pestle, filter cloth.

\section{PROCEDURE OF KRATKY METHOD USING INORGANIC NUTRIENTS}

The coco peats are submerged in water till they absorb the water and swell up. A small hole is made in the swollen coco peat and around 2-3 spinach seeds are placed inside and the hole covered back again. Seeds should be planted a minimum of $1 / 2$ inch deep, so that the pericarp, which is the outer covering of the seed, is removed by the friction of the media when the hypocotyl emerges. The spinach seeds are placed in a site, where they will germinate. Germination will take place in an area, that has the ability to control temperature (72-79 F, 22-26 C) and where the humidity is close to 100\%. After planting, the seeds should be lightly misted with a spray mist bottle or a hose mist nozzle. The seeds can be placed in a corner of a greenhouse or in a room, that receives no sunlight. The container in which seeds are to be placed, should be kept warm and humid. The temperature the seedlings are exposed to, will change the time to emerge. ${ }^{[9]}$

Seeds are started in a germination area, where they germinate in 2 days, in the dark. Make up stock solutions and store in separate bottles, with appropriate labels. Add each component to $800 \mathrm{~mL}$ de ionized (or Reverse osmosis, RO) 
water and then fill to $1 \mathrm{~L}$. Then stock solutions are poured into the crate and the system is to be made ready. Two separate systems were made. One using autoclaved distilled water and the other using normal tap water. The system using a nutrient solution made in distilled water is set as the Control System and the system using a nutrient solution made with tap water is set as the Test System. The seeds placed in the dark to germinate are now placed under the light for the seedlings to grow. After around 1 week, the seedlings may be transplanted into net pots, which are later moved to the growing tanks. The lower part $(1 / 2-1$ inch) of the net pots should be immersed in nutrient solution. The growing medium in the net pot becomes moistened by capillary action, providing water to the seedlings. ${ }^{[9]}$ As the plants grow, the nutrient solution level will drop below the net pots and the nutrient solution level is lowered by evaporation and transpiration. Due to this, an expanding air space full of moisture is created beneath the tank cover which protects the roots from drying. Hence, direct capillary wetting of the growing medium is not possible, but the expanding root system easily absorbs nutrients and water from the tank. Roots which occupy the moist air space above the nutrient solution undergo vigorous lateral and branching growth and have been described as "oxygen roots" whose main function is aeration. Roots extending into the nutrient solution have a limited elongation capability, because the oxygen content of the nutrient solution becomes progressively lower with depth, and they are considered to be "water and nutrient roots." ${ }^{[5]}$ The nutrient solution level should not be raised, as this will cause the plant to "drown." Monitoring of $\mathrm{pH}, \mathrm{EC}$ (electrical conductivity) and temperature is done daily. A major problem in a non-circulating system is that mosquitoes can breed and become a health hazard and create a nuisance to workers as well. Sides of the system can be screened using cardboard to prevent mosquito's access. Windows are cut into the cardboard and covered with filter cloth to allow air to pass through. Harvesting is conducted on day 16 and is often performed manually with scissors or an automatic knife. ${ }^{[5]}$ Various conditions such as temperature (22-26 C), $\mathrm{pH}$ (5.6-6), EC (1300+/- microseconds/cm), water temperature (24-26 C) are to be maintained. ${ }^{\text {[9] }}$ Various parameters, like number of days required for mature growth, number of leaves, leaf area index, wet and dry weight of root and shoots, are observed and recorded. Protein estimation of two samples taken from the Control system and Test system each was done using a UV spectrophotometer.

\section{OBSERVATIONS}

Table 1.2: Comparisons between Control System and Test System

\begin{tabular}{|l|c|c|}
\hline & CONTROL SYSTEM (after 15 days) & TEST SYSTEM (after 25 days) \\
\hline Leaf Area & $53 \mathrm{~cm}^{2}$ & $67 \mathrm{~cm}^{2}$ \\
\hline Number of Leaves & $30(12 \mathrm{big}, 18 \mathrm{medium})$ & $45(9 \mathrm{big}, 36 \mathrm{medium})$ \\
\hline \multicolumn{3}{|c|}{ Height of plant } \\
\hline Shoot & $25 \mathrm{~mm}$ & $32 \mathrm{~mm}$ \\
\hline Root & $37 \mathrm{~mm}$ & $46 \mathrm{~mm}$ \\
\hline \multicolumn{3}{|c|}{ Wet Weight of Plant } \\
\hline Shoot/Leaves & $97.87 \mathrm{~g}$ & $90 \mathrm{~g}$ \\
\hline Root & $18 \mathrm{~g}$ & $15 \mathrm{~g}$ \\
\hline \multicolumn{3}{|c|}{ Dry Weight of Plant } \\
\hline Shoot/Leaves & $10.22 \mathrm{~g}$ & $9.03 \mathrm{~g}$ \\
\hline Root & $3.212 \mathrm{~g}$ & $2.412 \mathrm{~g}$ \\
\hline Protein Concentration & $0.98 \mathrm{mg} / \mathrm{g}$ of leaf & $1.2 \mathrm{mg} / \mathrm{g}$ of leaf \\
\hline
\end{tabular}




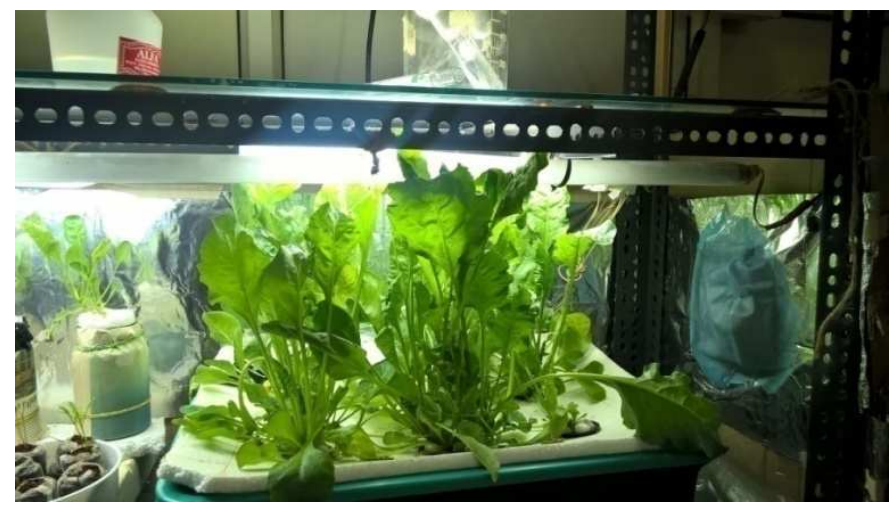

Figure 1.3: Day 25 - Test System

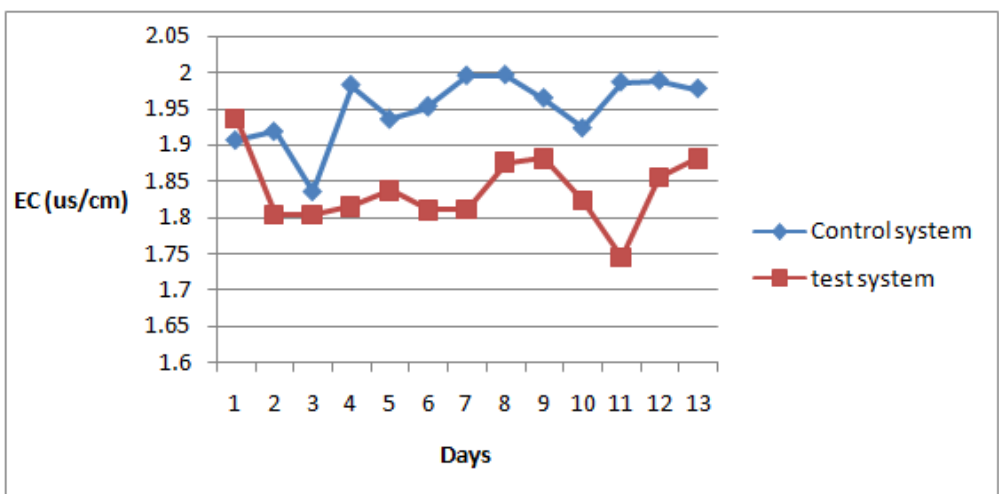

Graph 1.3: Variation of EC (Electrical Conductivity) w.r.t Time of Control system and Test system

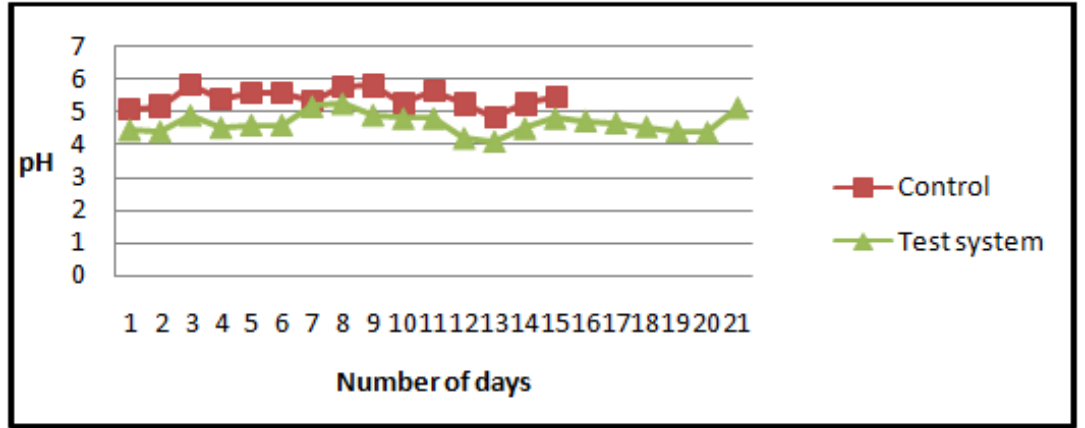

Graph 1.4: Comparison of variation of pH of Control system and Test system.

\section{VERMIPONICS (organic)}

Vermiponics is a soil-less growing technique, that combines hydroponics with vermiculture, by utilizing diluted worm bin leach ate ("worm tea"), as the nutrient solution. ${ }^{[12]}$ 2008, Saginaw Valley State University in Michigan was using vermiponics, as part of its efforts to reduce waste. ${ }^{[7]}$ Previously, it was noted by Aquaponic growers that, addition of red worms to the aquaponic grow beds was not only successful, but also served useful functions in the system. This has led several people to experiment with nutrient solutions that are based on worm bin leach ate alone, for instance in a Central Queensland University trial. ${ }^{[6]}$ Though the effectiveness of vermi ponics, compared to hydroponics and to aquaponics have not been studied thoroughly a paper from the University of Arizona found that, using worm tea has advantageous effects on root projection in lettuce seedlings, as compared to inorganic fertilizer. As hydroponics are based on feeding plant, inorganic fertilizer and as many aquaponic growers use a commercial fish feed, it has been suggested that, vermiponics is a 
more sustainable method of food production as worm castings can be used for local food waste rather than mined fertilizer or sea caught fish ${ }^{[6]}$

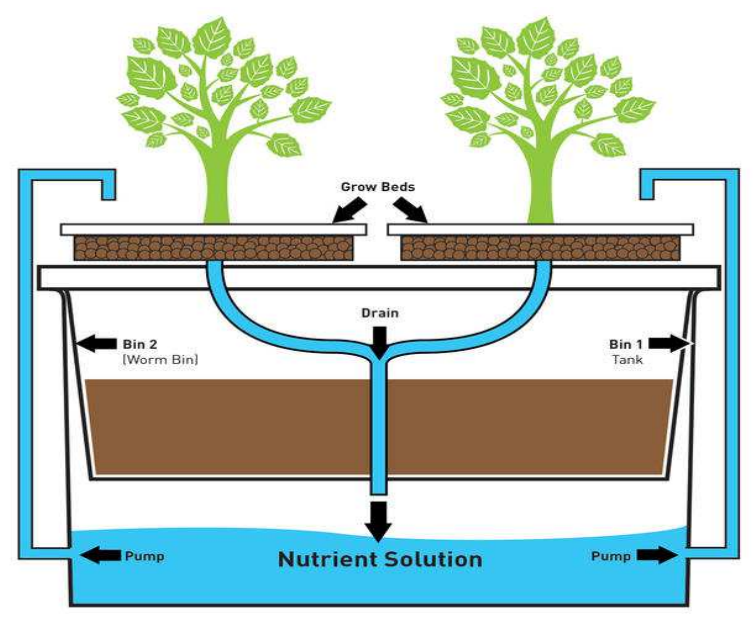

Figure 1.4: Schematic diagram of Vermiponics

\section{MATERIALS AND METHODS (For organic)}

\section{MATERIALS REQUIRED}

Organism Used

Red Earthworms (Eisenia fetida)

\section{Composting Material}

Dried leaves, twigs, wilted spinach leaves, manure, paper.

\section{Instruments}

Thermometer, pH meter, spargers, UV spectrophotometer, water bath

\section{Other Materials}

Stones, pebbles, sack, mortar and pestle

\section{PROCEDURE OF KRATKY METHOD USING ORGANIC NUTRIENTS VERMICOMPOST PIT}

Red earthworms (Eisenia fetida) were used for the composting process. ${ }^{[10]}$ The earthworms were weighed (350 g) and kept aside. A plastic bucket, having a small hole at the bottom to facilitate removal of the vermiliquid formed after composting, was used. The base of the plastic bucket is lined with a layer of small stones followed by a layer of mud and then the composting material is added. The composting material consisted of vegetable wastes, manure, dry leaves, paper, twigs and other perishable items. ${ }^{[1]}$ Once all the layers are ready, the system is watered well and the earthworms added to it. Parameters like $\mathrm{pH}$ of the system and temperature of the system is measured and monitored for good growth and composting activity of worms. Higher temperatures might result in decreased activity of the worms and even death. It is important to maintain a cool atmosphere. Since the system was set up in a closed room where the temperature was slightly higher, a wet sack is placed on top of the earthworms, so as to give them a cooler environment to settle in when the temperature of the organic matter rises. Spargers were attached for proper aeration of the system. The set up was kept 
undisturbed for 40 days, for complete composting of the organic matter. The vermiliquid formed was taken out every day, through the hole at the bottom, and collected in bottles. Parameters like $\mathrm{pH}$ and temperature of organic matter and $\mathrm{pH}$ and temperature of the vermiliquid were measured daily.

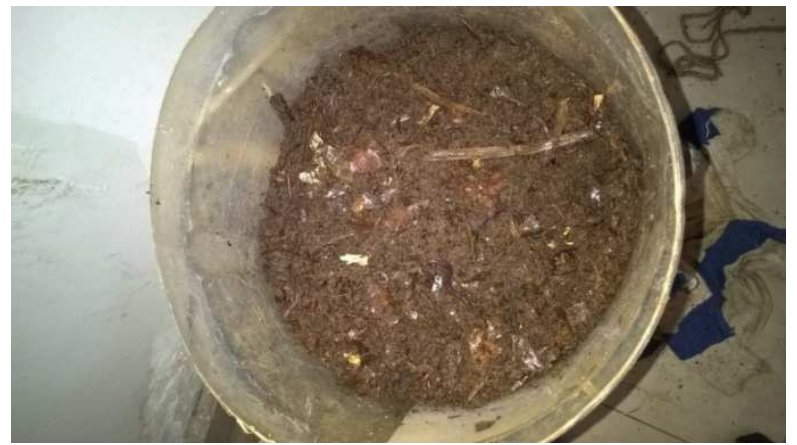

Figure 1.5: Setup of Vermi Compost Containing Organic Matter

\section{VERMIPONICS}

Two set ups were engineered, using the vermiliquid extracted and an artificial or store-bought vermiliquid. The set up using vermiliquid, extracted from the composting system was labelled set up A. After 40 days of composting the organic matter all the vermiliquid leached out was collected in a bottle and autoclaved. The autoclaved vermiliquid is then filtered and $320 \mathrm{~mL}$ of this nutrient media is used for growing spinach. The set up using the artificial vermiliquid was labelled set up B. The artificial vermiliquid was made with a ratio of 9:1. $50 \mathrm{~g}$ of the fertilizer was added in $500 \mathrm{ml}$ of normal tap water. This fertilizer and tap water mixture were kept in the shaker for 24 hours. After 24 hours, the mixture is autoclaved and filtered and $320 \mathrm{~mol}$ of this is used, for growing spinach. The coco peats are submerged in water till they absorb the water and swell up. A small hole is made in the swollen coco peat and around 2-3 spinach seeds are placed inside and the hole covered back again. Seeds should be planted a minimum of $1 / 2$ inch deep, so that the pericarp, which is the outer covering of the seed, is removed by the friction of the media when the hypocotyl emerges. The spinach seeds are placed in a site where they will germinate. After planting, the seeds should be lightly misted with a spray mist bottle or a hose mist nozzle. The seeds can be placed in a corner of a greenhouse or in a room that receives no sunlight. The container in which seeds are to be placed should be kept warm and humid. The temperature the seedlings are exposed to will change the time to emerge. ${ }^{[9]}$ Seeds are started in a germination area where they germinate in 2 days, in the dark. After around 1 week, the seedlings may be transplanted into net pots, which are later moved to the bottles of set up A and B. Parameters like number of leaves in a plant and the height of the plants were observed and measured daily. Protein estimation of sample taken from set up A was done using a UV spectrophotometer.

\section{OBSERVATIONS}

Table 1.5: Comparison of Number of Leaves of Setup A and Setup B

\begin{tabular}{|l|c|c|}
\hline \multicolumn{1}{|c|}{ Weeks } & SET UP A & SETUP B \\
\hline $1^{\text {st }}$ Week & 1 & 2 \\
\hline $2^{\text {nd }}$ Week & 6 & 8 \\
\hline $3^{\text {rd }}$ Week & 10 & 12 \\
\hline $4^{\text {th }}$ Week & 12 & 15 \\
\hline
\end{tabular}


Table 1.6: Comparison of Height of Plants of Set up A and Set up B

\begin{tabular}{|c|c|c|}
\hline Weeks & SET UP A & SET UP B \\
\hline $1^{\text {ST }}$ Week & $2.8 \mathrm{~cm}$ & $2.0 \mathrm{~cm}$ \\
\hline $2^{\text {nd }}$ Week & $3.8 \mathrm{~cm}$ & $2.8 \mathrm{~cm}$ \\
\hline $3^{\text {rd }}$ Week & $8.5 \mathrm{~cm}$ & $7 \mathrm{~cm}$ \\
\hline $4^{\text {th }}$ Week & $11.9 \mathrm{~cm}$ & $13.8 \mathrm{~cm}$ \\
\hline
\end{tabular}

Table 1.7: Composition of Vermicompost

\begin{tabular}{|l|c|}
\hline \multicolumn{1}{|c|}{ NUTRIENTS } & CONCENTRATION \\
\hline Nitrogen & $2.1 \%$ \\
\hline Phosphorus & $0.29 \%$ \\
\hline Potassium & $0.19 \%$ \\
\hline
\end{tabular}

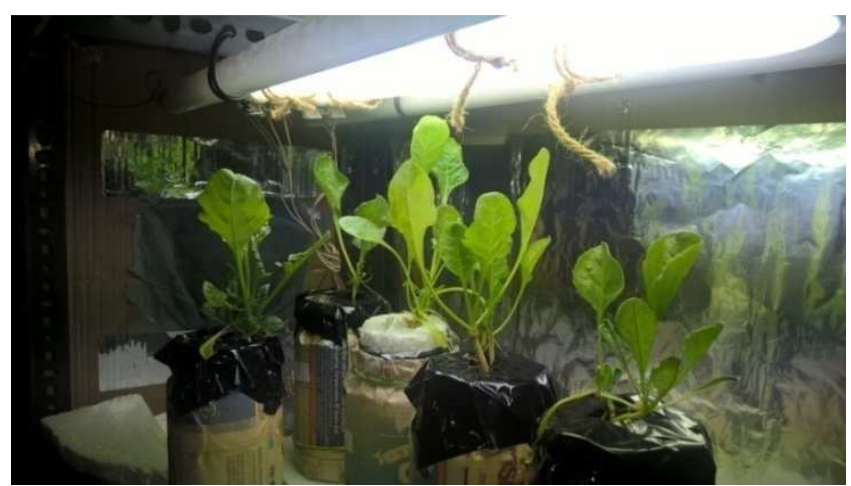

Figure 1.5: Day 15

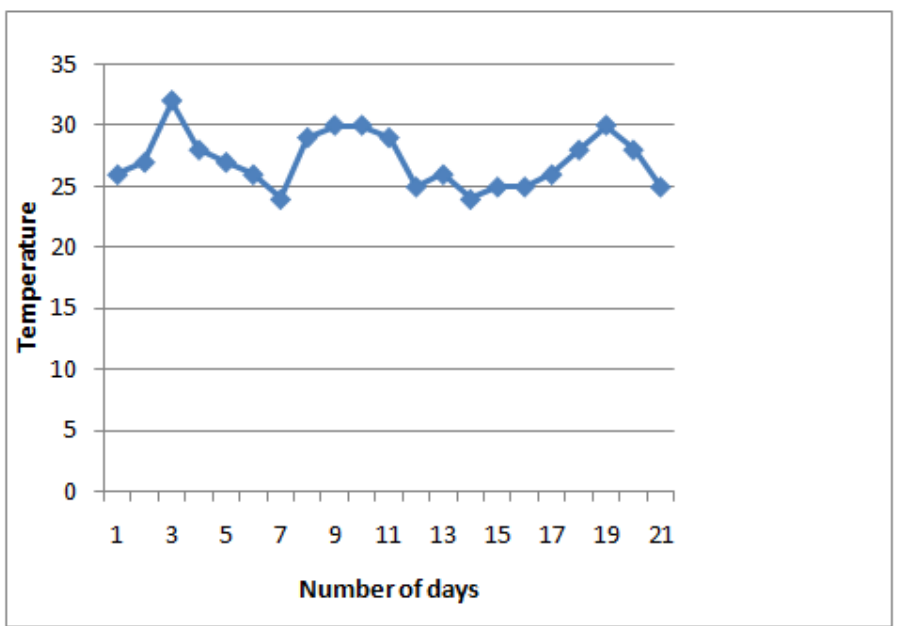

Graph 1.8: Variation of Temperature w.r.t Time of the Vermicompost Setup 


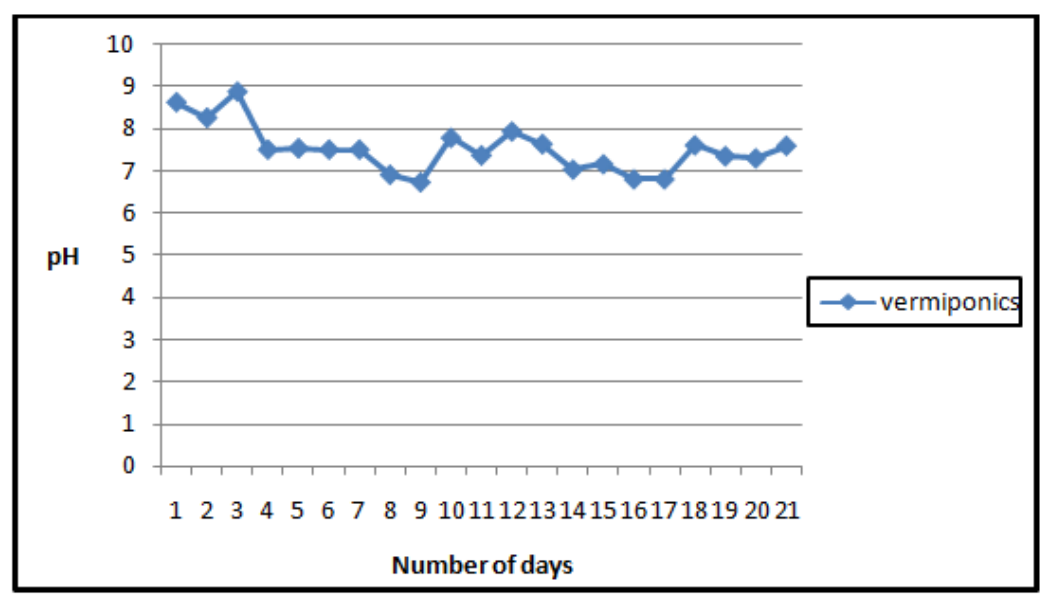

Graph 1.9: Variation of pH w.r.t Time of Control System, Test System and Vermiponic System

\section{INORGANIC}

\section{RESULTS}

Spinach (Spinacia oleracea) was successfully grown, using Kratky method in a laboratory setting. The Control system, using nutrients dissolved in distilled water, showed maturation in 15 days while the Test system, using nutrients dissolved in tap water, showed maturation in 25 days. The protein concentration of the sample from the Control system was found to be $0.98 \mathrm{mg} /$ gram of leaf sample, after 15 days. The protein concentration of the sample from the Test system was found to be $1.2 \mathrm{mg}$ / gram of leaf sample, after 25 days.

\section{CONCLUSIONS}

Thus, from the above experiments and observations, it can be concluded that Spinach plant can be successfully grown in a non-circulating hydroponic system in a laboratory setting using both distilled water and tap water. The system has grown in tap water takes longer to mature as compared to system grown in distilled water. The rate of growth is much faster and the quality of the leaves and the plant is better when compared to traditional growth of spinach using soil.

\section{ORGANIC}

\section{RESULTS}

Spinach (Spinacia Oleracea) was grown using vermiliquid formed from the composting of organic matter using red earthworms (Eisenia fetida). The vermiliquid was formed within 40 days and there was considerable growth of the plants, within 3 weeks. The growth of plants using artificial vermiliquid was found to be same, as the rate of growth of plants using organic vermiliquid. The protein concentration of the sample was found to be $0.93 \mathrm{mg} / \mathrm{gram}$ of leaf sample.

\section{CONCLUSIONS}

Thus, from the above experiments and observations, it can be concluded that, spinach plant can be successfully grown in a hydroponic system, using vermiliquid in place of water. There is no requirement of adding any external inorganic nutrients or compounds, for the growth. 


\section{REFERENCES}

1) Hoagland and Arnon (1950). The water-culture method for growing plants without soil. Berkeley, Calif.: University of California, College of Agriculture, Agricultural Experiment Station

2) du Toit LJ; Kirby HW \& Pedersen WL (1997). "Evaluation of an Aeroponics System to Screen Maize Genotypes for Resistance to Fusarium graminearum Seedling Blight.". Plant Disease 81 (2): 175-179. doi:10.1094/pdis.1997.81.2.175

3) Jones Jr, J. Benton. "Hydroponics: its history and use in plant nutrition studies." Journal of plant Nutrition 5.8 (1982): 10031030.

4) Furutani, S.C. and L. Arita-Tsutsumi, L. 2001. Use of Bacillus thurengiensis israelensis and methoprene to control Asian tiger mosquito, Aedes albopictus (Skuse) (Diptera: Culicidae), in non-circulating hydroponic tanks. Proc. Hawaiian Entomol. Soc $35: 113-119$

5) Kratky, B.A. 2004. A suspended pot, non-circulating hydroponic method. Proceedings of the South Pacific Soilless Culture Conference, Acta Hort. 648. p. 83-89.

6) Brett R. Roe and David J. Midmore (2008), "Sustainable Aquaponics", Practical Hydroponics \& Greenhouses

7) Jeff Kart (May 8, 2008). "SVSU reducing its food, paper waste with garbage-eating, compost-making worms"

8) "CIA Factbook: India". CIA Factbook. Central Intelligence Agency. Archivedfrom the original on 11 June 2008. Retrieved 2008-06-10

9) Kratky, B.A. 2009. Three non-circulating hydroponic methods for growing lettuce. Proceedings of the International Symposium on Soilless Culture and Hydroponics. Acta. Hort. 843:65-72

10) Effect of Vermiwash and Vermicomposting Leachate in Hydroponics Culture of Indian Borage (Plectranthus ambionicus) Plantlets July 2012. Shlrene Quaik, Asha Embrandiri, Parveen F. Rupani, Rajeev P. Singh, Mahamad H. Ibrahim, Environmental Technology Division, School of Industrial Technology, Universiti Sains Malaysia, Penang 11800, Malaysia Institute of Environment and Sustainable Development, Banaras Hindu University, Varanasi-5, India

11) Bio-conversion of Food Wastes into Vermicompost and Vermiwash M. M. Manyuchi., A. Phiri., P. Muredzi, N. Chirinda. International Journal of Science and Modern Engineering (IJISME) ISSN: 2319-6386, Volume-1, Issue-10, September 2013

12) Shlrene Quaik, Rajeev Pratap Singh, and Mahamad Hakimi Ibrahim (2014), "Growth Impact, Photosynthetic Pigments and Heavy Metals Content of Coleus aromaticus: A Vermiponic Approach" (PDF), Journal of Sustainability Science and Management 9 (1): 49-55

13) Gul Shamim, Khan M.H, Khanday B.A, Nabi Sabeena 2015. Effect of sowing methods and NPK levels on growth and yield of rain-fed Maize. 